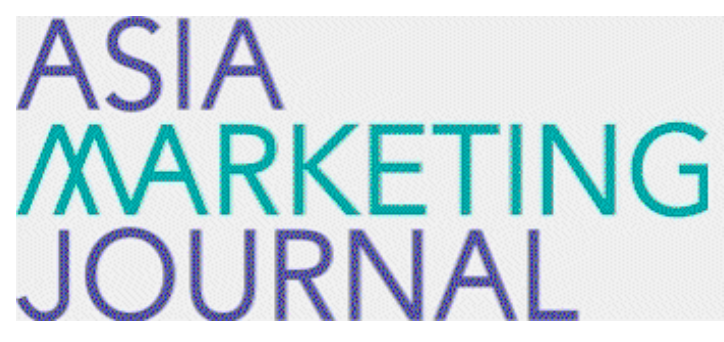

ASIA MARKETING JOURNAL

Volume 20 | Issue 1

Article 1

4-30-2018

\title{
Effects of Marketing Communication Capabilities on the link between Corporate Social Responsibility on Firm Value
}

YongHee Kim

Follow this and additional works at: https://amj.kma.re.kr/journal

Part of the Marketing Commons

\section{Recommended Citation}

Kim, YongHee (2018) "Effects of Marketing Communication Capabilities on the link between Corporate Social Responsibility on Firm Value," Asia Marketing Journal: Vol. 20 : Iss. 1 , Article 1.

Available at: https://doi.org/10.15830/amj.2018.20.1.1

This Article is brought to you for free and open access by Asia Marketing Journal. It has been accepted for inclusion in Asia Marketing Journal by an authorized editor of Asia Marketing Journal. 


\title{
Effects of Marketing Communication Capabilities on the link between Corporate Social Responsibility on Firm Value: Observations from the Service Industry*
}

\author{
YongHee Kim**
}

\begin{abstract}
An increasing number of studies have examined the effects of corporate social responsibility (CSR) activities on corporate financial performance (CFP) in the service industry. However, the extant literature does not provide comprehensive insights into the conditions on which the CSR CFP link relies. In this study, firms' marketing communication capability (MCC) is introduced as an important contingency variable, which determines the effects of CSR on the corporate financial performance, in the context of restaurant businesses. Multiple year data on the spending of public restaurant chains on different media are collected, and MCC is subsequently measured using the data envelope analysis. Then, a test is conducted to prove whether MCC moderates the relationship between CSR and firm financial performance. The empirical results support the hypothesis that MCC strengthens the effect of CSR on CFP. Through the findings, this research provides several interesting and important implications to the literature and managers of service firms.
\end{abstract}

Key words: service industry, restaurant industry, marketing communication capabilities, advertising, media spending, firm value, Tobin's Q

\section{Introduction}

Theory posits that corporate social responsibility (CSR) activities enable firms to obtain legitimacy and achieve reputational benefits through enhanced relationships with external and internal stakeholders, such as customers, employees, investors, and communities (Barnett \& Salomon, 2006; Hillman \& Keim, 2001; Surroca, Tribó, \& Waddock, 2010; Wang, Choi, \& Li, 2008). The enhanced relationships with different stakeholders allow firms to increase their financial performance. Several studies in management and marketing

\footnotetext{
* This work was supported by a 2-Year Research Grant of Pusan National University.

** Associate Professor of Marketing School of Business Pusan National University (kimyh@pusan.ac.kr)
} 
empirically showed the positive link between CSR and corporate financial performance (CFP).

On the other hand, some scholars suggested that CSR exerts negative or no significant effects on CFP. For example, Freidman (1970) argued that focusing on CSR may distract firms from their core businesses and cause the deterioration of financial performance. In addition, CSR programs are costly and may thus make little (or even negative) contribution to firms' financial performance (Kim \& Kim, 2014). Empirically, some studies showed the insignificant (Berman, Wicks, Kotha, \& Jones, 1999; Mahon \& Griffin, 1997) or negative (Berman et al., 1999; Brown \& Dacin, 1997) relationship between CSR and CFP.

Likewise, prior research regarding the performance implications of the CSR activities of service firms (e.g., hotels and restaurants) yielded mixed results. For example, Lee and Heo (2009) reported the insignificant impact of CSR on firm value in the restaurant industry, whereas Kang et al. (2010) reported the positive impact of CSR. Studies found CSR to have significant positive effects on the firm value of hotels (Kang et al., 2010; Lee \& Heo, 2009), but insignificant effects of CSR on the CFP were reported for casino firms (Inoue \& Lee, 2011; Lee \& Park, 2009; Kang et al., 2010).

The inconclusive findings have led to calls for contingency-based approaches that identify the circumstances under which CSR investments provide greater (or smaller) financial returns to service firms (Barnett, 2007; Youn, Hua, \& Lee, 2015). Thus far, several studies in management and marketing have introduced different contingency variables to shed lights on the impact of CSR on CFP. These variables include (1) environmental factors (Schnietz \& Epstein, 2005), (2) firm-specific factors (Luo \& Bhattacharya, 2006; McWilliams \& Siegel, 2000), and (3) industry factors (Ullmann, 1985). However, the literature regarding service firms does not pay much attention to moderators that can clarify the CSR - CFP relationship. To the best of my knowledge, only a few studies (Lee et al., 2013a, Lee et al., 2013b; Singal, 2014; Youn et al., 2015) considered moderating effects in examining the CSR CFP link in the service industry. According to these studies, the effects of CSR on CFP are significantly influenced by firm size (Youn et al., 2015), economic conditions (Lee et al., 2013a), and oil price (Lee et al., 2013b).

A crucial assumption in the literature regarding CSR - CFP is that stakeholders accurately acknowledge the types of CSR activities that firms engage in and that stakeholders appreciate the reasons behind such firms' investments in CSR. In other words, firms benefit from CSR activities only when stakeholders value these investments (Baron, 2001; McWilliams \& Siegel, 2001). Rogers (2013) reported in Forbes that firms spend \$50-100 million on their CSR programs, but only about five percent of such firms see promising returns on their investment 
in CSR. The main reason for the poor return on investment (ROI) is that stakeholders, especially customers, do not know what firms do in terms of CSR (Rogers, 2013). Thus, firms must effectively communicate the value of their CSR activities with their stakeholders to ensure the financial success of their CSR programs. That is, a firm's capability of capitalizing CSR investments into value for shareholders (i.e., financially engaged stakeholders) is dependent on its communication capabilities. At present, no empirical study in the service literature has examined servce firms' capabilities of communicating with different stakeholders about their strategic CSR actions as a contingency factor for the relationship between CSR and CFP.

To fill this research gap, this study proposes firms' marketing communication capability (MCC) as a proxy for their capability of communicating with stakeholders. Specifically, whether MCC strengthens the effectiveness of CSR was examined. MCC refers to the productivity of a firm's marketing initiatives in attaining positive outcomes, such as enhanced customer satisfaction, sales, and firm value. The restaurant firms are chosen for the context of this study as they have been struggled more than any other service firms for their unfavorable influences on the society such as producing too much food waste and causing public health problems (Tristano, 2015). The social criticisms urge restaurant firms to engage in CSR activities and further motivate the firms to have the public aware of such activities to ease the social concerns for the restaurant firms, which makes them the ideal context to investigate the link between CSR and CFP in the service industry and how the firms' MCC influence the link.

MCC for restaurant firms was measured using the data envelope analysis (DEA) method with unique data on firms' spending on different media in multiple years. Then the moderating effects of MCC on the relationship between CSR and CFP in the restaurant industry were measured. It was found that MCC is an important contingency variable that determines the effect of CSR on CFP. With the findings, this study provides substantial contributions to the service marketing literature and to practitioners in the service industry as a whole.

\section{Literature Review}

\subsection{Marketing Communication Capability (MCC)}

Marketing initiatives (e.g., advertising, promotion, and public relations) are investments used to communicate the value of offerings to consumers and ultimately create consumer demand. Marketing initiatives also create intangibles (e.g., consumer satisfaction, brand equity, and corporate reputation) that positively contribute to firm value not only by increasing future cash flows but also 
by decreasing the volatility of cash flows (Gruca \& Rego, 2005; McAlister, Srinivasan, \& Kim, 2007: Srivastava, Shervani, \& Fahey, 1998).

Although marketing investments are typically focused on the product market, the effect of marketing communication initiatives (and the resulting intangibles) spillovers into the stock market. For example, stock market participants highly favor familiar stocks and thus gain major ownership of such stocks (Joshi \& Hanssens, 2010). Additionally, the broad ownership created by advertising may insulate stock returns from market downturns (Grullon, Kanatas, \& Weston, 2004; McAlister, Srinivasan, \& Kim, 2007). Consistent with this notion, Kim and McAlister (2011) showed that advertising spending is positively related to stock returns, as indicated by their findings based on a multi-industry sample of firms over a 26-year period. These findings show that advertising affects not only consumer demand in the product market but also the investment decisions of financial market participants, such as investors and analysts in the security market.

Furthermore, several marketing studies emphasized the importance of the productivity (or efficiency) of marketing investments in creating value for firms through improved communications with stakeholders. Empirically, marketing studies develop methodologies to measure firms' MCC in recognition of firms' interest in maximizing their marketing communication investments (Kumar \& Peterson, 2004). For example, Dutta, Narashimhan, and Rajiv (1999) measured firms' marketing capabilities by applying stochastic frontier estimation to firm-level marketing expenditure ${ }^{1)}$ and sales data and showed that their measure of marketing capabilities is associated with firm value (Tobin's Q). Mittal, Anderson, Sayrak, and Tadikamalla (2005) estimated firms' efficiencies in transforming advertising expenditure into consumer satisfaction by using DEA and found a positive relationship between efficiency and firm value (Tobin's $Q$ ). Luo and Donthu (2007) also found that MCC estimated on the basis of DEA exhibits a curve linear impact on firm value (Tobin's $Q$ and stock returns). These marketing studies emphasized that MCC is an important marketing variable that influences firm value. Following the literature on MCC, the MCC of restaurant firms was measured using the DEA method, which is used to measure a firm's productivity in transferring a dollar spent on advertising into its desired outcomes.

\subsection{CSR and CFP: Moderating Role of MCC}

Corporate capabilities denote firms' expertise and competencies along numerous dimensions, including their ability to improve the quality of

1) They considered selling, general, and administrative spending as marketing expenditures and measured the firm-level marketing capabilities. 
existing products and services, generate innovative products and services, and communicate the improved attributes of existing products and services and the value of innovative products and services to stakeholders (Dutta et al., 1999; Gatignon \& Xuereb, 1997; Luo \& Bhattacharya, 2006: Luo \& Donthu, 2006; Rust, Moorman, \& Dickson, 2002; Zeithaml, 2000). According to the literature, the relationship between CSR and firm value is contingent on corporate capabilities (e.g., Brown \& Dacin, 1997). As CSR activities consume large resources, they place a financial burden on firms, which questions the financial benefits of those activities. For example, CSR investments that are made to the detriment of investments into the development of innovative products and improvement of product quality tend to harm firm financial performance (Sen \& Bhattacharya, 2001). Furthermore, consumers may engage in negative word of mouth after experiencing poor product quality; hence, undertaking CSR initiatives at the expense of investments in product quality and innovativeness may harm corporate image (Brown \& Dacin, 1997; Varadarajan \& Menon, 1988). In the same vein, Luo and Bhattacharya (2006) empirically identified product quality and innovative capability as moderating factors in the relationship between CSR and firm performance.

MCC is also an important corporate capability that determines the financial outcomes of the CSR activities of firms. Prior studies highlighted the importance of communicating CSR initiatives to different stakeholders to capitalize CSR into financial returns (e.g., Maignan \& Ferrell, 2004). Firms benefit from CSR activities only when stakeholders acknowledge the value of these investments (Baron, 2001; McWilliams \& Siegel, 2001). Firms with comprehensive MCC are likely to deliver messages of their CSR efforts and the value of such efforts to their stakeholders in an effective and efficient manner (Mishra \& Modi, 2016). Thus, a firm's ability to effectively communicate with its stakeholders is an essential prerequisite for the success of its CSR program. However, studies in the service literature have yet to consider firms' MCC as an important variable that moderates and clarifies the inconclusive CSR - CFP relationship. The present study bridges the gap by examining the moderating effect of a restaurant firm's MCC on the relationship between its CSR and CFP.

Advertising that informs consumers of CSRrelated product attributes may create a reputation that relates to quality, reliability, or honesty; such advertising makes consumers aware of product differentiation (quality) based on CSR attributes (McWilliams \& Siegel, 2000). Because CSR-related product attributes may be difficult for consumers to understand, communicating these attributes effectively to them is necessary for a firm to benefit from its CSR activities (McWilliams \& Siegel, 2000). For example, typical service businesses like hotels spend a 
considerable amount of costs in building and managing eco-friendly hotel buildings (Harrison, 2014). Also, increasing number of restaurant firms use locally grown and/or healthier food ingredients like cage-free eggs and non-GMOs (Tristano, 2015). Yet customers may not notice and understand such CSR efforts unless these firms actively and effectively communicate their investment in the eco-friendly buildings and use of sustainable ingredients with their customers. The marketing literature also suggested that firms using CSR as a value-adding differentiation should effectively communicate their CSR actions to their target customers (e.g., Luo \& Bhattacharya, 2009). A recent marketing paper by Mishra and Modi (2016) showed with an across-industry sample that overall marketing capability, which includes capability of managing marketing information and implementing marketing, positively moderates the effects of CSR on shareholder value. Although they did not test with MCC, their results also suggest that the restaurant firms with a better marketing communication would better translate their CSR investment into CFP.

Hypothesis: Restaurant firms' MCC positively moderates the relationship between CSR and CFP.

\section{Methods}

\subsection{Data}

Publicly listed restaurant firms in the US were identified on the basis of the Standard Industrial Classification (SIC) code. The firms whose SIC code is 5812 were considered the firms in the restaurant industry. To measure the MCC of such firms, firm-level media spending data between 2000 and 2008 were obtained from the Kantar Media Inc.'s report on top 1,000 media spenders. The report records selected organization's annual spending on 11 media outlets: TV, Magazines, Sunday Magazines, Newspapers, National Newspapers, Outdoor Advertising Services, Network Television, Spot Television, Syndication, Cable Television, Network Radio, and National Spot Radio. ${ }^{2)}$ Considering a firm's media spending for different media outlets as such firm's marketing communication efforts, the MCC of the sample restaurant firms was measured for each year. To measure firm-level CSR activities, the data on CSR performance were collected from the "MSCI ESG social ratings" database, which was known as KLD. These data were used to measure the CSR scores of the sample restaurant firm, which denote the corporate social performance of such firm each year. Financial statement

2) National Newspaper was excluded for the years between 2000 and 2006 in the Ad \$pender database. 
data were also obtained from COMPUSTAT and stock return data from the Center for Research on Stock Prices (CRSP) to measure the control variables in the estimation models. Using the data from the above sources, a panel data of restaurant firms whose CSR scores and media spending data were available were conducted. The final sample includes 165 firm-year observations for 28 restaurant firms.

\subsection{Measures}

Regression models to predict Tobin's Q (i.e., an indicator of $\mathrm{CFP}$ ) with the focal independent variables (i.e., MCC and CSR) and the interaction between MCC and CSR were developed, to test the proposed hypothesis with a sample of restaurant firms. In this section, I describe how I measured the variables used in the regression models.

Dependent variable: Tobin's Q. Tobin's Q is typically used as the measure of a firm's financial performance. Several studies in the CSR literature used Tobin's Q as the objective measure to test the effect of CSR (e.g., Inoue \& Lee, 2011; Kang et al., 2010; Kim \& Kim, 2014; Lee \& Heo, 2009). Tobin's Q is a forwardlooking measure of firm performance. Thus, it reflects not only the current performance of the firm but also the prospective performance of the firm (Rao, Agarwal, \& Dahlhoff, 2004). With Tobin's Q reflecting the future performance of a firm, it has been used as the dependent variable to test whether a strategic variable, such as marketing spending, CSR, and R\&D, is associated with firm value (e.g., Kim \& Kim, 2014; Morck, Shleifer, \& Vishny, 1988; Waddock \& Graves, 1997; Mittal et al., 2005; Rao et al., 2004). Tobin's Q was also used as the dependent variable to test the impacts of CSR and the moderating effect of MCC. Tobin's Q was measured following the works of Kaplan and Zingales (1997); Gompers, Ishii, and Metrick (2003); and Bebchuk, Cohen, and Ferrell (2009). Tobin's Q in this study is described in equation 1.

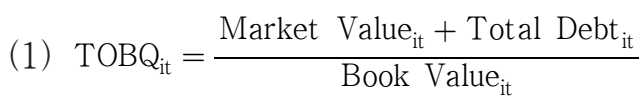

For the hypothesis test, Tobin's Q at $t+1$ was used as the dependent variable (i.e., all the independent variables are one-year lagged independent variables) to rule out the reverse causality concern (McAlister et al., 2007).

\subsubsection{Focal independent variable 1: CSR}

The CSR of restaurant firms was measured with MSCI ESG social ratings. MSCI ESG social ratings include the seven categories of CSR activities, namely, community relations, corporate governance, diversity issues, employee relations, environmental issues, human rights, and product quality. MSCI ESG rates firms in terms of their "strengths" (socially responsible 
actions) and "concerns" (socially irresponsible actions) in each category. Then, each action is scored one point as a "strength" or a "concern." In examining the moderating effect of MCC on the relationship between CSR and CFP, only CSR-strength (socially responsible activities) scores were considered. While firms communicate their socially responsible activities through various channels, they do not announce their socially irresponsible activities (Scalet \& Kelly, 2010). Thus, a firm's MCC is relevant to its socially responsible activities (i.e., CSR-strength).

\subsubsection{Focal independent variable 2: MCC}

A restaurant firm's MCC was measured using DEA. This method is used to measure a firm's productivity ${ }^{3)}$ in generating outputs with a given amount of inputs relative to other firms in the same industry. The DEA is a wellestablished method for measuring a firm's productivity in translating marketing-related inputs into performance outputs. For example, Luo and Donthu (2006) used the DEA approach to measure marketing communication productivity and found that this productivity measure is associated with firm value. Mittal et al. (2005) estimated a firm's ability to use marketing to create intangible assets using the DEA and showed that this capability is associated with firm value. Raithel et al. (2011) measured a firm's MCC using the DEA approach with firm-level spending on different media outlets as inputs and with sales as outputs. Also, Brown and Ragsdale (2002) used the DEA approach to estimate a firm's productivity in translating the respondent ratings of hotel chains into customer satisfaction. Using the DEA approach, Wöber and Fesenmaier (2004) estimated a firm's capability of generating accommodation sales and revenues using domestic and international advertising budgets. In this study, this well-established way of measuring a firm's productivity in generating firm performance outputs with different types of media spending was used.

Conceptually, the DEA approach enables researchers to identify which firms in a sample are in the best productivity frontier, that is, the ideal set of firms that are most productive in generating outputs with a given amount of inputs (e.g., Raithel et al., 2011). The firms in the frontier are considered as the best practice firms in a sample that translate inputs into outputs. Thus, the value of MCC for those firms in the frontier is 1 . Then, the relative productivity of a firm not in the frontier is measured on the basis of the distance between firm location and the best practice frontier. A shorter distance equates to higher productivity.

3) Some studies named the measure as "capabilities" or "efficiency." In this study, I denote the measure as "capabilities."

4) I performed DEA with the option of variable returns to scale assuming that marketing outputs can change not in proportion to changes in inputs; specifically, DEA was performed with the realistic assumption of variable returns to 
In this study, I selected different types of media spending as inputs and sales growth and Tobin's $Q$ as outputs to run the DEA and estimate the MCC of restaurant firms. Generally, restaurant chains utilize different media outlets to communicate the value of their products to their customers (e.g., Kim, Kim, \& O’Neill, 2013). Thus, media spending is an important communication tool for restaurant firms. However, the effect of media spending is not realized in the short term but in the long term; in particular, media spending is different from other types of marketing spending, such as sales promotion (Mela, Gupta, \& Lehmann, 1997). Thus, longterm performance measures were considered as the outputs of media spending. In particular, sales growth and Tobin's Q were used as the output measures for media spending. This selection of inputs and outputs, which focuses on long-term measures, is appropriate for the present study because the firms that are capable of translating long-term-oriented inputs into long-term performance are likely to capitalize their CSR activities into long-term financial performance.

As previously mentioned, I collected data for spending on 11 media outlets from Kantar Media Inc. from 2000 to 2008. Instead of using media spending for all the 11 media outlets, the 11 media outlets were categorized into three types of media spending: print (magazines, Sunday magazines, newspapers, and national newspapers), broadcast (network television, spot television, syndicated television, cable television networks, network radio, and national spot radio), and outdoor media. This categorization was well accepted by previous studies that estimated MCC using the DEA with Ad \$spender data (Luo \& Donthu, 2006; Raithel et al., 2011). Thus, the annual spending on print, broadcast, and outdoor media were used as inputs. As for the outputs, sales growth was measured in terms of sales increases or decreases in comparison with previous year sales (i.e., sales at year $t$ divided by sales at year $t-1$ ). Tobin's $Q$ was measured on the basis of equation 1 .

Using the selected inputs and outputs, DEA was performed on the sample of restaurant firms between 2000 and 2008 in an annual basis, which measured a restaurant firm's MCC in a year. ${ }^{5)}$ That is, in the sample, the MCC for the best performing firms takes the value of 1 , whereas that for the other firms is between 0 and 1 , which represents the distance between the firm and the line linking the best performing firms on the productivity frontier.'

scale (see Raithel et al., 2011).

5) Previous studies on the DEA approach indicated that to obtain a valid measure of MCC, sample size should be more than 10 (e.g., Golany \& Roll, 1989). In this study, the sample size in a sample year was over 10. Thus, I did not experience the sample size problem in running the DEA approach.

6) See Delmas et al. (2007) for further details of DEA. 


\subsubsection{Control variables}

The set of control variables used in the Tobin's Q model includes firm size (SIZE), leverage (LEV), marketing intensity (MKT), and year dummies (YR_dum). The data for the control variables were collected from COMPUSTAT. Marketing intensity was measured by taking advertising expenditures scaled by total assets. Marketing intensity indicates the amount of a firm's marketing efforts and is not the firm's capability of using the marketing expenditure; hence, the effect of marketing intensity on Tobin's Q must be controlled to single out the moderating effect of MCC.

\subsection{Model and Estimation}

The sample only included firm-year observations whose media spending data are available. One may be concerned about the presence of sample selection bias. That is, the restaurant firms whose media spending data are available may be different from those without media spending. This difference may influence the results. Heckman two-stage approach was used to address the concern of sample selection bias, (Heckman, 1979). In the first stage, the probability that the firm utilizes media spending data (i.e., inclusion in the top 1,000 media spenders) was predicted by developing a probit model. Oneyear lagged firm size, Tobin's $Q$, and year dummies were used as independent variables in the first stage of the probit model. The inverse Mills ratio was measured by performing the probit regression, which enabled us to control sample selection bias. That is, the estimated inverse Mills ratio (Inverse_Mill) was included in the second stage of the model (i.e., the main Tobin's Q model) as an additional control variable. The second stage of the main model, which tests the proposed hypothesis, is described as

(2) $\mathrm{TOBQ}_{\mathrm{it}+1}=\alpha_{1}+\beta_{1} \mathrm{CSR}_{\mathrm{it}}+\beta_{2} \mathrm{MCC}_{\mathrm{it}}$

$$
\begin{aligned}
& +\beta_{3} \mathrm{CSR}_{\mathrm{it}} \times \mathrm{MCC}_{\mathrm{it}}+\beta_{4} \mathrm{X}_{\mathrm{it}} \\
& +\beta_{5} \text { Inverse_Millit }_{\mathrm{it}} \\
& +\beta_{6} \text { Year_dum } \mathrm{t}+\varepsilon_{\mathrm{it}},
\end{aligned}
$$

where $\mathrm{i}$ indexes a firm, $\mathrm{t}$ indexes a year, $\mathrm{X}_{\mathrm{it}}$ is the set of all control variables (i.e., $\mathrm{X}_{\mathrm{it}}=$ Marketing intensity $y_{i t}, \mathrm{ROA}_{i t}$, Firm size $\mathrm{i}_{\mathrm{i}}$, and Leverage $\left._{\mathrm{it}}\right), \alpha_{1}$ is the intercept term, $\varepsilon_{\mathrm{it}} \sim$ i.i.d. $\mathrm{N}\left(0, \sigma^{2}\right)$, and Year_dumt denotes the year dummies.

The significance of the estimated coefficients was tested with standard errors clustered by firm. The use of firm-level clustered errors in dealing with potential bias from correlated errors across sample years within a firm is well

7) For the marketing spending variable, I used advertising expenditures (data45) in COMPUSTAT. The definition of the item includes both media spending and promotional spending. In a broad sense, advertising expenditure in COMPUSTAT is considered as marketing expenditure. 
accepted in the accounting and finance literature (Petersen, 2009). Thus, the same firm-level clustered standard errors were used to deal with the potential bias from the panel data structure when testing the significance of the estimated coefficients.

\section{Empirical Results}

\subsection{Summary Statistics and Bivariate Correlations}

The summary statistics of the variables and the correlations among the variables used in the model (equation 2) are presented in Table 1.

As expected, the correlation between CSR and Tobin's Q and the correlation between MCC and Tobin's $\mathrm{Q}$ were both positive and significant $(\rho=0.342, p<0.01 ; \rho=0.224, p$ $<0.01$, respectively), which suggests that both
MCC and CSR are positively related to CFP. The correlation between MCC and CSR was not significant $(\rho=-0.040, p>0.10)$. The insignificant correlation suggests that including MCC and CSR in one model does not cause a multicollinearity problem.

\subsection{Regression Results}

The results from the estimation of equation 2 are provided in Table 2 .

First, the effects of CSR on the Tobin's Q of a restaurant firm were significantly positive ( $b$ $=0.487, \mathrm{p}<0.05$; column 1$)$. A significant positive relationship was also found between the MCC and Tobin's Q of a restaurant firm $(b=0.369, p<0.01 ;$ column 2), consistent with: the same relationship is described in the literature. When CSR and MCC are both included in one model, their effects on Tobin's $\mathrm{Q}$ at $t+1$ were still positive and significant ( $\mathrm{b}$ $=0.375, \mathrm{p}<0.01 ; \mathrm{b}=0.493, \mathrm{p}<0.01 ;$ column

〈Table 1〉 Descriptive Statistics and Correlation Table

\begin{tabular}{|c|c|c|c|c|c|c|c|c|c|}
\hline $\mathrm{NO}$ & VAR & $\mathrm{M}$ & S.D. & (1) & (2) & (3) & (4) & (5) & (6) \\
\hline (1) & $\mathrm{TOBQ}_{\mathrm{t}+1}$ & 2.21 & 1.01 & & & & & & \\
\hline (2) & $\mathrm{MCC}_{\mathrm{t}}$ & 0.90 & 0.12 & $0.224^{* * *}$ & & & & & \\
\hline (3) & $\mathrm{CSR}_{\mathrm{t}}$ & 0.04 & 0.07 & $0.342^{* * *}$ & -0.040 & & & & \\
\hline (4) & $\mathrm{MKT}_{\mathrm{t}}$ & 0.06 & 0.03 & -0.036 & $-0.161^{* *}$ & $-0.391^{* * * *}$ & & & \\
\hline (5) & $\mathrm{SIZE}_{\mathrm{t}}$ & 7.05 & 1.17 & 0.109 & $-0.171^{* *}$ & $0.604^{* * * *}$ & $-0.396 * * *$ & & \\
\hline (6) & $\mathrm{LEV}_{\mathrm{t}}$ & 0.39 & 0.47 & $0.256^{* * *}$ & -0.041 & -0.117 & $0.225^{* * *}$ & $-0.190 * *$ & \\
\hline (7) & Inverse__Mill $t_{\mathrm{t}}$ & 0.77 & 0.44 & -0.069 & $0.215^{* * * *}$ & $-0.449 * * *$ & $0.369^{* * *}$ & $-0.898 * * *$ & $0.253^{* * * *}$ \\
\hline
\end{tabular}


〈Table 2〉 The Effects of CSR, MCC, and the interactions on Tobin's Q

\begin{tabular}{|c|c|c|c|c|}
\hline DV: Tobin's Qt+1 & $(1)$ & $(2)$ & (3) & $(4)$ \\
\hline \multirow[t]{2}{*}{$\mathrm{CSR}_{\mathrm{t}}$} & $0.487^{* *}$ & - & $0.375^{* * *}$ & -1.143 \\
\hline & $(2.32)$ & & $(2.81)$ & $(-1.47)$ \\
\hline \multirow[t]{2}{*}{$\mathrm{MCC}_{\mathrm{t}}$} & - & $0.369^{* * * *}$ & $0.493^{* * * *}$ & $0.251^{* *}$ \\
\hline & & $(2.86)$ & $(4.12)$ & $(2.60)$ \\
\hline \multirow[t]{2}{*}{$\mathrm{CSR}_{\mathrm{t}} \times \mathrm{MCC}_{\mathrm{t}}$} & - & - & - & $1.563^{* *}$ \\
\hline & & & & $(2.21)$ \\
\hline \multirow[t]{2}{*}{$\mathrm{MKT}_{\mathrm{t}}$} & 0.076 & 0.061 & 0.172 & 0.149 \\
\hline & $(0.46)$ & $(0.45)$ & $(1.36)$ & $(1.31)$ \\
\hline \multirow[t]{2}{*}{$\mathrm{SIZE}_{\mathrm{t}}$} & 0.455 & -0.131 & -0.055 & 0.338 \\
\hline & $(1.29)$ & $(-0.25)$ & $(-0.15)$ & $(0.79)$ \\
\hline \multirow[t]{2}{*}{$\mathrm{LEV}_{\mathrm{t}}$} & $0.334^{* *}$ & 0.315 & $0.349^{* *}$ & $0.357^{* * *}$ \\
\hline & $(2.45)$ & $(1.62)$ & $(2.54)$ & $(2.53)$ \\
\hline \multirow[t]{2}{*}{ Inverse_Millt } & 0.199 & -0.036 & -0.083 & 0.223 \\
\hline & $(0.58)$ & $(-0.08)$ & $(-0.27)$ & $(0.68)$ \\
\hline \multirow[t]{2}{*}{ Intercept } & -4.387 & 2.289 & -1.359 & -3.400 \\
\hline & $(-1.52)$ & $(0.54)$ & $(-0.48)$ & $(-1.10)$ \\
\hline Observations & 165 & 165 & 165 & 165 \\
\hline $\mathrm{R}$-squared & 0.250 & 0.274 & 0.382 & 0.404 \\
\hline
\end{tabular}

Note: *** $\mathrm{p}<.01,{ }^{* *} \mathrm{p}<.05,{ }^{*} \mathrm{p}<.10$.

The t-statistics calculated with standard errors adjusted by two-dimensional clustering (i.e., clustering by firm and year) are in parentheses. All the estimated coefficients are standardized coefficients. The estimated coefficients for year dummies are not reported.

3). This positive relation indicates that a potential multicollinearity does not hamper the interpretations of the effect of CSR and MCC on Tobin's Q. The interaction between MCC and CSR exhibited significant and positive effects on Tobin's $\mathrm{Q}$ ( $b=1.563, \mathrm{p}<0.05)$, as shown in column 4 of Table 2. Thus, the results support the hypothesis. That is, a restaurant firm's CSR is more effective in enhancing CFP when the firm's MCC is higher.

12 ASIA MARKETING JOURNAL Vol.20 No.01 April 2018

\subsection{Additional analysis and robustness check}

Although the results suggest that high-MCC firms enhance CFP with a better CSR communication with investors, one can concern that a firm's MCC (i.e., marketing communication in product market) may not be correlated with the firm's CSR communication with investors (i.e., CSR communication in financial market). To address this concern, data on whether each sample 
firm included a separate CSR section in its annual report or provides a separate CSR report to the financial community were collected. Assuming that those restaurant firms giving CSR section or report communicate better their CSR with investors, I checked the correlation between MCC and a dummy of whether the firm provides rich discussion on CSR in its financial reports. It was found that the correlation is highly significant and positive $(\rho=0.20$, $\mathrm{p}$-value $<0.01)$, which suggest that firms with a high MCC tend to give richer discussion on their CSR and its implications with investors. Thus, this additional data collection and the correlation test eases the potential concern on whether MCC reflects the firm's capability on CSR communication.

I also performed a robustness check using an alternative measure of CSR. Some previous CSR studies suggested the use of only five

〈Table 3〉 Robustness Tests: The Effects of CSR, MCC, and the interactions on Tobin's Q (with alternative measure of CSR)

\begin{tabular}{lccc}
\hline \multicolumn{1}{c}{ DV: Tobin's $\mathrm{Q}_{\mathrm{t}+1}$} & $(1)$ & $(2)$ & $(3)$ \\
\hline $\mathrm{aCSR}_{\mathrm{t}}{ }^{2}$ & $0.487^{* *}$ & $0.493^{* * *}$ & -1.168 \\
$\mathrm{MCC}_{\mathrm{t}}$ & $(2.31)$ & $(2.80)$ & $(-1.50)$ \\
& - & $0.375^{* * *}$ & $0.250^{* *}$ \\
$\mathrm{aCSR}_{\mathrm{t}} \times \mathrm{MCC}_{\mathrm{t}}$ & & $(4.13)$ & $(2.59)$ \\
& & - & $1.586^{* *}$ \\
MKT $_{\mathrm{t}}$ & & & $(2.24)$ \\
& 0.062 & 0.172 & 0.149 \\
SIZE $_{\mathrm{t}}$ & $(0.46)$ & $(1.36)$ & $(1.32)$ \\
& -0.134 & -0.058 & 0.343 \\
LEV $_{\mathrm{t}}$ & $(-0.25)$ & $(-0.15)$ & $(0.80)$ \\
& 0.315 & $0.349 * *$ & $0.357^{* *}$ \\
Inverse_Mill & $(1.62)$ & $(2.54)$ & $(2.53)$ \\
& -0.038 & -0.085 & 0.227 \\
Intercept & $(-0.09)$ & $(-0.27)$ & $(0.69)$ \\
& 2.311 & -1.337 & -3.422 \\
\hline Observations & $(0.55)$ & $(-0.48)$ & $(-1.11)$ \\
R-squared & 165 & 165 & 165 \\
\hline
\end{tabular}

Note: *** $\mathrm{p}<.01,{ }^{* *} \mathrm{p}<.05,{ }^{*} \mathrm{p}<.10$.

${ }^{1} \mathrm{aCSR}_{\mathrm{t}}$ is an alternative measure of positive corporate social responsibility. The t-statistics calculated with standard errors adjusted by two-dimensional clustering (i.e., clustering by firm and year) are in parentheses. All the estimated coefficients are standardized coefficients. The estimated coefficients for year dummies are not reported. 
(instead of seven) MSCI ESG CSR categories, which represent the level of corporate voluntary activities for primary stakeholders; these five categories are Community, Environment, Diversity, Employment, and Humanity (Inoue \& Lee, 2011; Berman et al., 1999; Hillman \& Keim, 2001; Kacperczyk, 2009, Clarkson, 1995; Kim \& Kim, 2014). The regression model is estimated with the CSR scores for the five aforementioned categories. The results are summarized in Table 3.

Consistent with the results reported in Table 2, the alternative measure of CSR and MCC exhibits a positive impact on Tobin's $\mathrm{Q}$ at $\mathrm{t}+$ $1(b=0.493, p<0.01 ; b=0.375, p<0.01$, respectively; column 2). More important, the results for the moderating role of MCC in the relationship between CSR and Tobin's $\mathrm{Q}$ at $\mathrm{t}$ +1 are consistent $(b=1.586, p<0.05$, column $3)$. The results confirm that the moderating effect of MCC on the CSR - CFP link is robust to how to construct CSR scores.

\section{Discussion and Conclusion}

This study proposed MCC as an important contingent variable that determines the effects of CSR on financial performance of service firms. The empirical results suggest that firms with great marketing communication capabilities generate high financial returns from CSR.
These findings provide several important and interesting implications to the literature and the practitioners in the service industry.

\subsection{Theoretical and Managerial Implications}

CSR studies showed mixed results on the effect of CSR on CFP (Kim, Kim, \& Qian, 2015, forthcoming). Accordingly, researchers today attempt to identify key contingencies in which CSR is capitalized as financial returns to shed light on the inclusive link between CSR and CFP. This study joins the important research stream by introducing MCC as an important contingency variable in the service industry and thus makes several important contributions to the literature of CSR-CFP of service firms.

First, the study offers contributions to the stakeholder theory applied to the relationship between CSR and CFP. Stakeholder theory suggests that various stakeholders (e.g., customers, employees, and investors) are likely to make voluntary contributions to a firm when that firm engages in numerous CSR activities (e.g., Wang \& Qian, 2011). However, these voluntary contributions of stakeholders should be dependent on their understanding and appreciation of the firm's CSR activities and the consequences of such activities. Even though stakeholders are willing to support socially responsible firms, they may not make actual contributions to firm performance unless they acknowledge the 
CSR activities of such firm and appreciate the value of such activities. Hence, firms need to actively and effectively inform stakeholders about their various CSR activities and help them understand the consequences and value of the activities. This requirement highlights the importance of a firm's MCC in realizing the financial benefits of investing in CSR activities. The results of this study empirically show that firms that communicate effectively with their stakeholders obtain great returns on their CSR investment.

Second, this study contributes to the literature on the marketing - finance interface. The marketing literature shows that different marketing variables influence financial performance (Srinivasan \& Hannsens, 2009). Several marketing studies indicated that MCC is a marketing metric associated with CFP (e.g., Dutta et al., 1999; Mittal et al., 2005; Luo \& Donthu, 2007). This study goes beyond showing the link between MCC and CFP and proposes that MCC contributes to CFP as an important contingency variable in the effect of various strategic variables that affect CFP. Specifically, it is theorized how MCC can increase the effect of CSR on CFP. Therefore, this work contributes to the marketing - finance interface literature by confirming the effect of MCC on CFP and by testing MCC as a moderator in the relationship between CSR and CFP.

Third, the results of this study contribute to the rich stream of research on the effects of
CSR on CFP in the service industry. Several studies in the service management and marketing literature focused on restaurant service firms' CSR and examined its effects on different measures of shareholder value. However, little attention has been paid to the factors that moderate the relationship between CSR and CFP. The present study is one of only a few studies that have examined the moderators of the CSR - CFP link. Moreover, the moderators identified by previous studies are given conditions for firms rather than firm-determined factors that firm managers can influence. Economic conditions (Lee et al., 2013a) and oil price (Lee et al., 2013b) are given market conditions that firm managers cannot control. Moreover, the influence of a firm's management on firm size is limited (Youn et al., 2015). Thus, extant studies provided practitioners with ways to adapt to and play in a given condition so as to drive good financial outcomes from CSR. Conversely, MCC is very much dependent on managerial efforts. Thus, the present study provides further insights into how managers can enhance the value creating effects of CSR. Specifically, this study suggests that effective communication with stakeholders is a cost effective way for a firm to maximize the benefits of CSR to financial outcomes. CSR is costly, and when such a costly investment does not yield satisfactory returns, it surely hurts a firm's financial health. Enhancing MCC could be a good strategy for a firm to improve ROI 
of CSR without incurring additional costs for developing other CSR activities.

\section{Future Studies}

Although this study provides interesting results for CSR researchers and restaurant practitioners, future studies may still add insights to the CSR - CFP literature. First, future studies can measure MCC and test its effect and moderating role in the relationship between CSR and CFP using samples of other service industries such as hotels, car rental, and airlines. The impact of MCC on the CSR - CFP link may differ depending on industry attributes. Second, the study tested the effect of MCC and its moderating effect on Tobin's Q, which is the level of shareholder value. Future studies can test the effects of MCC on other important financial performance metrics. For example, recent literature focuses on equity risk, which indicates the volatility of stock returns (e.g., Kim, Kim, \& O’Neill, 2013; Kim \& Kim, 2014). Further research can test the effect of MCC on equity risk and examine whether MCC is effective in reducing firm equity risk and whether MCC makes CSR effective in reducing that risk. Finally, researchers can measure firms' communication capabilities by using other types of marketing communication channels, such as direct marketing, public relation, and sales promotion. In the present study, MCC was measured using media spending because media advertising is considered the key communication channel in the restaurant industry. However, firms utilize various channels to communicate their products and strategies to stakeholders. Therefore, if data are available, future studies that measure a firm's capabilities of communicating using various channels other than media advertising would offer a comprehensive understanding of the role of MCC in determining the effects of CSR on CFP.

〈Received January 16. 2018〉

〈Accepted March 23. 2018〉

\section{References}

Barnett, M. L. (2007), Stakeholder influence capacity and the variability of financial returns to corporate social responsibility. Academy of Management Review, 32(3), 794-816.

Barnett, M. L. \& Salomon, R. M. (2006), Beyond dichotomy: the curvilinear relationship between social responsibility and financial performance. Strategic Management Journal, 27(11), 1101-1122.

Baron, D. (2001), Private politics, corporate social responsibility and integrated strategy. Journal of Economics and Management Strategy, 10, 7-45. 
Bebchuk, L, Cohen, A., \& Ferrell, A. (2009). What matters in corporate governance? Review of Financial Studies, 22(2), 783827.

Berman, S. L., Wicks, A. C., Kotha, S. \& Jones, T. M. (1999), Does stakeholder orientation matter? The relationship between stakeholder management models and firm financial performance. Academy of Management Journal, 42(5), 488-506.

Brown, J. \& Ragsdale, C. (2002). The competitive market efficiency of hotel brands: an application of data envelopment analysis. Journal of Hospitality \& Tourism Research, 26(4), 332-360.

Brown, T. J. \& Dacin, P. A. (1997). The Company and the Product: Corporate Associations and Consumer Product Responses. Journal of Marketing, 61(1), 68-84.

Clarkson, M. B. E. (1995). A stakeholder framework for analyzing and evaluating corporate social performance. Academy of Management Review, 20(1), 92-117.

Delmas, M., Russo, M., \& Montes-Sancho, M. (2007). Deregulation and environmental differentiation in the electric utility industry. Strategic Management Journal, 28(2), 189209.

Dutta, S., Narasimhan, O., \& Rajiv, S. (1999). Success in high technology markets: is marketing capability critical?. Marketing Science, 18(4), 547-568.

Gatignon, H. \& J. Xuereb (1997), Strategic
Orientation of the Firm and New Product Performance. Journal of Marketing Research, 34(Feb), 77-90.

Golany, B. \& Roll, Y. (1989). An application procedure for DEA. Omega, 17(3), 237250.

Gompers, P., Ishii, J., \& Metrick, A. (2003). Corporate governance and equity prices. The Quarterly Journal of Economics, 118 (1), 107-156.

Gruca, T. S. \& Rego, L. L. (2005). Customer satisfaction, cash flow, and shareholder value, Journal of Marketing, 69(July), 115-130.

Grullon, G., Kanatas, G. \& Weston, J. P. (2004). Advertising, breadth of ownership and liquidity. Review of Financial Studies, 17 (2), 439-461.

Harrison, K. (June, 2014). Green Hotels Are Leading The Pack On TripAdvisor. Forbes. Retrieved from https://www.forbes.com/ sites/kateharrison/2014/06/20/green-hotels -are-leading-the-pack-on-tripadvisor/ \#60f7fdf72917.

Heckman, J. (1979). Sample selection bias as a specification error. Econometrica, 47(1), 153-161.

Hillman, A. J., \& Keim, G. D. (2001). Shareholder value, stakeholder management, and social issues: What's the bottom line?. Strategic Management Journal, 22(2), 125-139.

Inoue, Y. \& Lee, S. (2011). Effects of different dimensions of corporate social responsibility 
on corporate financial performance in tourism-related industries. Tourism Management, 32, 790-804.

Joshi, A. \& Hanssens, D. M. (2010). The Direct and Indirect Effects of Advertising Spending on Firm Value. Journal of Marketing, 74(1), 20-33.

Kacperczyk, A. (2009). With greater power comes greater responsibility? Takeover power and corporate attention to stakeholders. Strategic Management Journal, 30(3), 261285.

Kang, K. H., Lee, S., \& Heo, C. (2010). Impacts of positive and negative corporate social responsibility activities on company performance in the tourism industry. International Journal of Hospitality Management, 29(1), 72-82. Kaplan, S. N. \& Zingales, L. (1997). Do investmentcash flow sensitivities provide useful measures of financing constraints?. The Quarterly Journal of Economics, 112(1), 169-215.

Kim, K. H., Kim, M. C., \& Qian, C. (2015). Effects of corporate social responsibility on firm financial performance: a competitiveaction perspective. Journal of Management (forthcoming).

Kim, M. \& McAlister, L. M. (2011). Stock market reaction to unexpected growth in marketing expenditure: negative for sales force, contingent on spending level for advertising. Journal of Marketing, 75(4), 68-45.

Kim, Y. \& Kim, M. (2014). Corporate social responsibility and shareholder value of restaurant firms. International Journal of Hospitality Management, 40, 120-129.

Kim, Y., Kim, M. O’Neill, J. (2013). Advertising and firm risk: A study of the restaurant industry. Journal of Travel \& Tourism Marketing, 30, 455-470.

Kumar, V. \& Petersen, A. (2004). Maximizing ROI or profitability. Marketing Research, 16(Fall), 28-34.

Lee, E. M., Park, S. Y., Lee, H. J. (2013a). Employee perception of CSR activities: its antecedents and consequences. Journal of Business Research, 66 (10), 1716-1724.

Lee, S. \& Heo, C.Y. (2009). Corporate social responsibility and customer satisfaction among US publicly traded hotels and restaurants. International Journal of Hospitality Management, 28, 635-637.

Lee, S. \& Park, S. (2009). Do socially responsible activities help hotels and casinos achieve their financial goals?. International Journal of Hospitality Management, 28, 105-112.

Lee, S., Seo, K., \& Sharma, A. (2013b). Corporate social responsibility and firm performance in the airline industry: the moderating role of oil prices. Tourism Management, 38, 20-30.

Luo, X. \& Bhattacharya, C. B. (2006), Corporate Social Responsibility, Customer Satisfaction, and Market Value. Journal of Marketing, 70(October), 1-18.

Luo, X. \& Bhattacharya, C.B. (2009), Debate 
over Doing Good: Corporate Social Performance, Strategic marketing Levers, and Firmidiosyncratic Risk. Journal of Marketing, 73(6), 198-213.

Luo, X. \& N. Donthu (2006), Marketing's credibility: a longitudinal investigation of marketing communication productivity and shareholder value. Journal of Marketing, 70(Oct), 70-91.

Mahon, J. F., \& Griffin, J. (1997). The corporate social performance and corporate financial performance debate. Business and Society, 36(1), 5-31.

Maignan, I. \& Ferrell, O.C. (2004). Corporate social responsibility and marketing: an integrative framework. Journal of the Academy of Marketing Science, 32(1), 3-19.

McAlister, Srinivasan, L., R., \& Kim, M. (2007). Advertising, research and development, and systematic risk of the firm. Journal of Marketing, 71(Jan), 35-48.

McWilliams, A. \& Siegel, D. (2000). Corporate social responsibility and financial performance: Correlation or misspecification? Strategic Management Journal, 21(5), 603-609.

McWilliams, A. \& Siegel, D. (2001). Corporate social responsibility: A theory of the firm perspective. Academy of Management Review, 26(1), 117-127.

Mela, C. F., Gupta, S. \& Lehmann, D. R. (1997). The long-term impact of promotion and advertising on consumer brand choice.
Journal of Marketing Research, 34(2), 248-261.

Mishra, S., \& Modi, S. B. (2016). Corporate Social Responsibility and Shareholder Wealth: The Role of Marketing Capability. Journal of Marketing, 80(1), 26-46.

Mittal, V., Anderson, E. W., Sayrak, A., \& Tadikamalla, P. (2005). Dual emphasis and the long-term financial impact of customer satisfaction. Marketing Science, 24(4), 544-555.

Morck, R., Shleifer, A., \& Vishny, R.W. (1988). Characteristics of hostile and friendly $t$ targets. In Alan J. Auerbach (ed.), Corporate Take-overs: Causes and Consequences. Chicago: University of Chicago Press.

Petersen, M. (2009). Estimating standard errors in finance panel data sets: comparing approaches. Review of Financial Studies, 22(1), 435-480.

Raithel, S. Scharf, S., Taylor, C., Schwaiger, \& Zimmermann. (2011). Marketing accountability: applying data envelopment analysis to assess the impact of advertising efficiency on shareholder value. Measurement and Research Methods in International Marketing, 22, 115-130.

Rao, V., Agarwal, M., \& Dahlhoff, D. (2004). How is manifest branding strategy related to the intangible value of a corporation?. Journal of Marketing, 68(4), 126-141.

Rogers, B. (October, 2013). Too many feelings and not too enough facts in CSR strategy. 
Forbes. Retrieved from http://www. forbes.com/sites/brucerogers/2013/10/07/ too-many-feelings-and-not-enough-facts -in-csr-strategy/ \#60ad79226e78.

Rust, R., Moorman, C., \& Dickson, P.R. (2002). Getting return on quality: cost reduction, revenue expansion, or both?. Journal of Marketing, 66, 7-24.

Scalet, S. \& Kelly, T. (2010). CSR rating agencies: what is their global impact?. Journal of Business Ethics, 94(1), 69-88.

Schnietz, K. E. \& Epstein, M. J. (2005). Exploring financial value of a reputation for corporate social responsibility during a crisis. Corporate Reputation Review, 7(4), 327-345.

Sen, S. and C.B. Bhattacharya (2001), Does Doing Good Always Lead to Doing Better? Consumer Reactions to Corporate Social Responsibility, Journal of Marketing Research, 38(May), 225-44.

Singal, M. (2014). Corporate social responsibility in the hospitality and tourism industry: do family control and financial condition matter?. International Journal of Hospitality Management, 36, 81-89.

Srinivasan, S. \& Hanssesns, D. M. (2009). Marketing and firm value: metrics, methods, findings, and future directions. Journal of Marketing Research, 46 (3), 293-312.

Srivastava, R., Shervani, T. \& Fahey, L. (1998). Market-based assets and shareholder value: a framework for analysis. Journal of
Marketing. 62(1), 2-18.

Surroca, J., Tribó, J.A., \& Waddock, S. (2010). Corporate responsibility and financial performance: the role of intangible resources. Strategic Management Journal, 31(5), 463-490.

Tristano, D. (October, 2015). How 10 food trends for 2016 will transform restaurants. Forbes. Retrieved from http://www. forbes.com/sites/darrentristano/2015/10/ 28/how-10-food-trends-for-2016-willtransform-restaurants/ \#215d502b5a35.

Ullmann, A. A. (1985). Data in search of a theory: a critical examination of the relationships among social performance, social disclosure, and economic performance of U.S. firms, Academy of Management Review, 10(3), 540-557.

Varadarajan, P. R. \& Menon, A. (1988). Cause-related marketing: a coalignment of marketing strategy and corporate philanthropy. Journal of Marketing, 68, $1-17$.

Waddock, S. A. \& Graves, S. B. (1997). The corporate social performance-financial performance link. Strategic Management Journal, 18(4), 303-319.

Wang, H., Choi, J., \& Li, J. (2008). Too little or too much? Untangling the relationship between corporate philanthropy and firm financial performance. Organization Science, 19(1), 143-159.

Wang, H. \& Qian, C. (2011). Corporate philanthropy 
and corporate financial performance: the roles of stakeholder response and political assess. Academy of Management Journal, 54(6), 1159-1181.

Wöber, K., \& Fesenmaier, D. R. (2004). A multi-criteria approach to destination benchmarking: A case study of state tourism advertising programs in the United States. Journal of Travel and Tourism Marketing, 16(2/3), 1-18.
Youn, H., Hua, N., \& Lee, S. (2015). Does size matter? Corporate social responsibility and firm performance in the restaurant industry. International Journal of Hospitality Management, 51, 127-134.

Zeithmal, V. (2000), Service quality, profitability, and the economic worth of customers: what we know and what we need to learn. Journal of the Academy of Marketing Science, 28(1) 67-85. 